\title{
Gambaran Kadar Kreatinin Serum pada Vegetarian Lacto-Ovo
}

\author{
${ }^{1}$ Anisa Septiana \\ ${ }^{2}$ Murniati Tiho \\ ${ }^{2}$ Yanti Mewo
}

\author{
${ }^{1}$ Program Studi Pendidikan Dokter Fakultas Kedokteran Universitas Sam Ratulangi Manado \\ ${ }^{2}$ Bagian Biokimia Fakultas Kedokteran Universitas Sam Ratulangi Manado \\ Email: aseptiana11_241@yahoo.com
}

\begin{abstract}
Creatinine is a residual product of the metabolism in the body which is generally used to estimate active tissues. Its precursor comes from protein. In vegetarians, their eating pattern affects the body condition. Lacto-ovo vegetarians consume all kinds of vegetable but do not consume any kind of meat; however, they still consume milk, egg, and daily product. This study was aimed to describe serum creatinine levels in lacto-ovo vegetarians. This was a descriptive study with a cross-sectional design. There were 25 respondents in this study. The results showed that 23 respondents had normal creatinine serum level, and 2 respondents had low creatinine serum level. The average score of creatinine serum level was $0.8 \mathrm{mg} / \mathrm{dL}$ $(\mathrm{SD} \pm 0.2 \mathrm{mg} / \mathrm{dL})$. Conclusion: The majority of lacto-ovo vegetarians had normal creatinine serum level.
\end{abstract}

Keywords: creatinin serum, lacto-ovo vegetarian

\begin{abstract}
Abstrak: Kreatinin merupakan produk sisa dari metabolisme tubuh yang biasanya digunakan untuk mengestimasi jaringan aktif tubuh. Prekursor kreatinin berasal dari protein makanan. Pola makan pada vegetarian berefek terhadap kondisi tubuh. Vegetarian lacto-ovo adalah tipe vegetarian yang mengonsumsi semua jenis sayur dan berpantang makan segala jenis daging tetapi masih mengonsumsi susu, telur, dan produk dari susu. Penelitian ini bertujuan untuk mengetahui kadar kreatinin serum pada vegetarian lacto-ovo. Jenis penelitian ialah deskpritif dengan desain potong lintang. Responden penelitian ini berjumlah 25 orang. Hasil penelitian memperlihatkan bahwa 23 responden memiliki kadar kreatinin serum normal dan 2 responden memiliki kadar kreatinin serum rendah. Rerata nilai kadar kreatinin serum responden yaitu 0,8 $\mathrm{mg} / \mathrm{dL}(\mathrm{SD} \pm 0,2 \mathrm{mg} / \mathrm{dL}$ ). Simpulan: Sebagian besar vegetarian lacto-ovo memiliki kadar kreatinin serum yang normal.
\end{abstract}

Kata kunci: kreatinin serum, vegetarian lacto-ovo

Saat ini pola makan vegetarian semakin popular. Bertambah banyaknya vegetarian menyebabkan banyak penelitian mengenai efek pola makan tersebut terhadap kondisi tubuh. Jumlah vegetarian yang terdaftar pada Indonesian Vegetarian Society (IVS) saat berdiri pada tahun 1998 yakni sekitar lima ribu orang dan meningkat menjadi enam puluh ribu anggota pada tahun 2007. Angka ini hanya mencakup sebagian kecil dari jumlah vegetarian yang sesungguhnya, karena tidak semua vegetarian mendaftar menjadi anggota. ${ }^{1}$

Vegetarian dibagi menjadi vegetarian murni dan vegetarian tidak murni. Vegetarian murni yaitu vegetarian yang hanya mengonsumsi makanan yang berasal dari tumbuh-tumbuhan misalnya sayur-sayuran, buah-buahan, roti, sereal, nasi, dan kacangkacangan. Vegetarian tidak murni yaitu vegetarian yang juga mengonsumsi makanan yang berasal dari tumbuh-tumbuhan namun mengonsumsi beberapa hasil produk hewani seperti, susu, dan telur. 
Salah satu contoh vegetarian tidak murni yaitu vegetarian lacto-ovo. ${ }^{2}$

Diet vegetarian yang teratur dengan baik banyak memberikan manfaat untuk kesehatan. Di sisi lain, vegetarian memiliki risiko menderita berbagai penyakit defisiensi nutrisi makro dan mikro, salah satunya ialah protein. Protein sangat penting sebagai sumber asam amino untuk pertumbuhan, perbaikan jaringan dan untuk sintesis enzim dan hormon. Di dalam tubuh, protein secara terus menerus dibentuk dan diurai sehingga simpanan asam amino di dalam sel naik turun. Senyawa yang berasal dari asam amino antara lain protein, hormon (tiroksin, epinefrin dan insulin), neurotransmiter, kreatin fosfat, hem pada hemoglobin dan sitokin, basa purin, piramidin pada nukleotida, dan asam nukleat. ${ }^{3,4}$

Kreatinin dibentuk di otot dari keratin fosfat melalui dehidrasi nonenzimatik yang ireversibel dan pengeluaran fosfat. ${ }^{5}$ Meskipun asupan protein memengaruhi kadar kreatinin, namun pengaruhnya tidak langsung karena kreatinin disintesis dari kreatin dengan menggunakan asam amino esensial yaitu arginin dan glisin sebagai prekursor kreatinin. Prekursor tersebut berasal dari protein dalam makanan. Kreatinin biasa digunakan untuk mengestimasi lean body mass (jaringan aktif tubuh). ${ }^{6}$

Hingga saat ini belum ada penelitian mengenai gambaran kadar kreatinin darah pada vegetarian lacto-ovo. Penelitian ini bertujuan untuk mendapatkan gambaran kadar kreatinin serum pada vegetarian lacto-ovo.

\section{METODE PENELITIAN}

Penelitian ini menggunakan metode deskriptif dengan desain potong lintang. Penelitian dilakukan mulai bulan Agustus 2015 sampai Januari 2016 di Universitas Klabat Airmadidi pada mahasiswa yang tergabung di komunitas Medical Ministry dan pemeriksaan sampel dilakukan di laboratorium Prodia.

Sampel pada penelitian ini sebanyak 25 buah yang diambil menggunakan metode total sampling dan sesuai kriteria inklusi. Data yang diambil diolah dengan menggunakan MS Excel 2007 dengan analisis univariat dan disajikan dalam bentuk narasi.

\section{HASIL PENELITIAN}

Berdasarkan jenis kelamin, responden laki-laki berjumlah 14 orang (56\%) dan responden perempuan berjumlah 11 orang (44\%). Sebagian besar responden berusia antara 20-30 tahun dengan jumlah 22 orang, dan sisanya berusia 15,18 , dan 19 tahun, masing-masing berjumlah satu responden.

Pemeriksaan laboratorium menunjukkan nilai rerata kadar kreatinin darah responden yaitu $0,8 \mathrm{mg} / \mathrm{dL} \quad(\mathrm{SD} \pm 0,2$ $\mathrm{mg} / \mathrm{dL}$ ), dan nilai tengah yaitu $1,00 \mathrm{mg} / \mathrm{dL}$. Nilai kadar kreatinin pada penelitian ini yang tersering yaitu $0,65 \mathrm{mg} / \mathrm{dL}$, sedangkan nilai maksimal $1,09 \mathrm{mg} / \mathrm{dL}$ dan nilai minimum $0,43 \mathrm{mg} / \mathrm{dL}$ dengan nilai rentang $0,66 \mathrm{mg} / \mathrm{dL}$.

\section{BAHASAN}

Berdasarkan hasil penelitian ini, kadar kreatinin darah terbanyak (96\%) dalam batas normal. Kreatinin merupakan hasil metabolism keratin yang sebagian besar (98\%) berada dalam jaringan otot, dan hanya sebagian kecil keratin tubuh ditemukan dalam jaringan hati, ginjal, dan otak serta cairan tubuh. ${ }^{7}$

Kreatinin tidak dapat digunakan ulang sehingga merupakan produk sampah. Kreatinin diekskresi hampir seluruhnya oleh ginjal kecuali pada gagal ginjal berat dimana 5-10\% ekskresi lewat usus karena degradasi kreatinin oleh pertumbuhan berlebihan bakteri dalam usus halus. Sebanyak 2/3 ekskresi harian kreatinin dapat terjadi melalui eliminasi eksternal renal pada pasien dengan penurunan fungsi ginjal berat, sehingga ekskresi kreatinin diurin lebih rendah pada orang dengan penyakit ginjal. $^{8}$

Sumber utama kreatinin dalam plasma ialah metabolism normal keratin fosfat dalam otot. Sebagian besar keratin ditemukan dalam jaringan otot. ${ }^{7,9}$ Dalam keratin fosfat, residu fosfat memiliki potensial 
kimia sama dengan yang ada pada ATP dan karena itu dengan mudah ditransfer ke adenosine difosfat (ADP). Sebaliknya, ketika ATP cukup, keratin fosfat diambil dari ATP dan keratin. Kedua proses tersebut dikatalis oleh keratin kinase. Pada otot yang relaks, bentuk keratin fosfat seharusnya memiliki level ATP yang cukup. Jika ada penurunan drastis dari level ATP selama kontraksi, hal itu dapat diperbaiki dalam waktu singkat dengan menyintesis ATP dari keratin fosfat dengan ADP. ${ }^{9}$

Keratin bukan derivat dari otot itu sendiri, tetapi disintesis melalui dua tahap di ginjal dan hati. Asalnya, gugus guadino dari arginin yang diubah menjadi glisin di ginjal dan menghasilkan guadinoasetat. Di hati, N-metilasi dari guadinoasetat dibentuk dalam formasi keratin. Koenzim dalam reaksi ini ialah S-adenosylmethionin. ${ }^{10}$ Kadar kreatinin darah dipengaruhi oleh beberapa faktor seperti perubahan masa otot, aktivitas fisik yang berlebihan, konsumsi obat-obatan yang dapat meningkatkan kadar kreatinin darah, kenaikan sekresi tubulus dan dekstruksi kreatinin internal serta diaet kaya daging yang dapat meningkatkan kadar kreatinin. ${ }^{11}$ Hasil penelitian Hascemy ${ }^{12}$ menunjukkan adanya hubungan antara asupan protein dengan kadar kreatinin. Dari hasil penelitian didapatkan 10 responden bodybuilder berjenis kelamin laki-laki memiliki kadar kreatinin serum yang tinggi. Semua responden yang memiliki kadar kreatinin serum tinggi merupakan responden yang mengonsumsi makanan tinggi protein seperti dada ayam, putih telur, dan daging sapi tanpa lemak.

Metabolisme protein merupakan suatu proses di mana protein dipecah oleh tubuh menjadi asam amino melalui proses katabolisme dan kemudian disintesis dalam jaringan yang membutuhkannya melalui proses anabolisme. Protein yang diserap oleh tubuh dapat ditemukan dalam bentuk protein nabati dan protein hewani. Protein nabati berasal dari kacang-kacangan dan biji-bijian. Sayuran dan buah-buahan tidak terlalu memberikan sumber protein pada tubuh karena kandungan protein pada keduanya. Protein hewani yang umum digunakan sebagai sumber protein ialah telur, unggas, ikan, dan daging. ${ }^{13}$

Pada penelitian ini juga ditemukan satu responden perempuan berusia 15 tahun yang memiliki kadar kreatinin dibawah normal. Faktor usia juga memengaruhi kadar kreatinin dalam darah. Menurut nilai rujukan laboratorium Prodia normalnya kadar kreatinin dalam darah yaitu: untuk usia neonatus $<1,20 \mathrm{mg} / \mathrm{dL}$; untuk usia 212 bulan $<0,90 \mathrm{mg} / \mathrm{dL}$; usia $>1-18$ tahun $<1,00 \mathrm{mg} / \mathrm{dL}$; sedangkan untuk usia dewasa laki-laki 0,70-1,2 dan untuk usia dewasa perempuan $0,50-0,90 \mathrm{mg} / \mathrm{dL} .{ }^{14}$

Penurunan kadar kreatinin juga dapat terjadi pada gagal jantung kongestif, syok, dan dehidrasi serta keadaan glomerulonefritis, nekrosis tubular akut akibat gangguan fungsi sekresi kreatinin. Pada keadaan tersebut terjadi penurunan perfusi darah ke ginjal sehingga makin sedikit pula kadar kreatinin yang dapat difiltrasi oleh ginjal. $^{15}$

\section{SIMPULAN}

Dari hasil penelitian ini dapat disimpulkan bahwa sebagian besar vegetarian lacto-ovo memiliki kadar kreatinin serum yang normal.

\section{DAFTAR PUSTAKA}

1. American Dietetic Association, Position of the American Dietetic Association. Vegetarian diets. Journal of the American Dietetic Association. 2009; 109:1266-82.

2. Key TJ, Appleby PN, Rosell MS. Health Effects of Vegetarian and Vegan Diets. Proceeding of the Nutrition Society. 2006; 65:35-41.

\section{Pongsibidang FAK, Tiho M, Kaligis SHM.} Gambaran kadar albumin serum pada vegetarian lacto - ovo. eBm. 2016;1:2.

4. Marks DB, Marks AD, Smith CM. Biokimia Kedokteran Dasar. Jakarta: EGC, 2000; p. 556.

5. Murray RK, Granner DK, Rodwell VW, editors. Biokimia Harper (27th ed). Pendit BU, alih bahasa. Wulandari N, Rendy L, Dwijayanthi L, Liena, Dany F, Rachman LY, editor edisi bahasa 
Indonesia. Jakarta: EGC, 2012; p. 283.

6. Nugrahani A. Hubungan asupan protein terhadap kadar urea nitrogen, kreatinin, albumin darah pasien penyakit ginjal kronik yang menjalani hemodialisis di RSUP Dr. Sardjito Yogyakarta [Skripsi]. Yogyakarta: Universitas Gadjah Mada; 2007.

7. Schlattner U, Tokarska-Schlattner M, Wallimann T. Mitochondrial creatine kinase in human health and disease. Biochim Biophys Acta. 2006;1762(2): 164-80.

8. Widyastiti NS. Perbedaan nilai klirens Cockcroft-Gault berdasarkan hasil pemeriksaan kreatinin metode Jaffe uncompensated, rate-blanked compensated dengan enzimatik [Skripsi]. Semarang: Universitas Diponegoro; 2016.

9. Metabolisme ureum-kreatinin [cited 2015 Nov 18]. Available from: https://www. scribd.com/doc/119030453/metabolism e-ureum-kreatinin\#download

10. Koolman J, Roehm KH. Color Atlas of Biochemistry (2nd ed). New York:
Flexibook, 2005 p. 336-7.

11. Rinawati S. Perbandingan hasil pemeriksaan kreatinin darah metode Jaffe Reaction antara deproteinasi dan tanpa deprotenasi di Laboratorium Seger Waras Jepara [Skripsi]. Semarang: Universitas Muhammadiyah Semarang; 2010.

12. Hascemmy $\mathbf{N}$. Hubungan asupan protein dengan kadar ureum dan kreatinin pada bodybuilder [Skripsi]. Semarang: Universitas Diponegoro; 2011.

13. Ma'shumah N, Bintanah $\mathrm{S}$, Handarsari $\mathrm{E}$. Hubungan asupan protein dengan kadar ureum, kreatinin, dan kadar hemoglobin darah pada penderita gagagl ginjal kronik hemodialisa rawat jalan di RS Tugurejo Semarang. Jurnal Gizi Universitas Muhammadiyah Semarang. 2014: 3:28-9.

14. Hasil pemeriksaan kadar kreatinin serum di Laboratorium Prodia. Directory of Services Prodia 2014-2015.

15. Verdiansah. Pemeriksaan fungsi ginjal. CDK-237.2016;43:148-54. 